\title{
Environmental Sustainability in Higher Education: Mapping the Field
}

\section{Sostenibilidad ambiental en la educación superior: una revisión del campo}

\author{
Luis Francisco Miranda (1) https://orcid.org/0000-0002-5139-4914 \\ Jorge Oswaldo Sánchez Buitrago (2) https://orcid.org/0000-0002-9299-6647
}

Javier de Jesús Viloria Escobar (3) https://orcid.org/0000-0002-2396-4190

(1) Universitat de Barcelona

(2) Universidad de Magdalena

(3) Instituto Nacional de Formación Técnica Profesional Humberto Velásquez García

(Received: April 7, 2019; accepted for publishing: September 6, 2019)

How to cite: Miranda, L. F., Sánchez, J. O. y Viloria, J. de J. (2021). Environmental sustainability in higher education: Mapping the field. Revista Electrónica de Investigación Educativa, 23, e09, 1-16. https://doi.ora/10.24320/redie.2021.23.e09.4053

\section{Abstract}

A considerable amount of literature has been published on environmental sustainability in the context of higher education. However, no previous studies have investigated how environmental sustainability has evolved in the university context and little is known about the specific research trends in this field. In that sense, the main purpose of this study is to identify the most influential topics in university environmental sustainability research and the relationships between them. To that end, we conducted a keyword cooccurrence analysis of scientific articles published between 1989 and 2019 . We were able to identify 23 core keywords. We then designed a map of associations between the terms, representing the relationships between them in thematic clusters. We found at least three major areas supporting environmental sustainability research in universities: environmental education, environmental sustainability integration, and environmental protection. Each research area is analyzed and discussed.

Keywords: sustainability, environmental sustainability, environmental education, higher education

\section{Resumen}

Se ha publicado una gran cantidad de literatura sobre la sostenibilidad ambiental en el contexto de la educación superior; sin embargo, no existen estudios previos que hayan investigado de qué manera la sostenibilidad ambiental ha evolucionado en el contexto universitario y poco se sabe sobre las tendencias de investigación propias a este campo. El propósito principal de este estudio es identificar los temas más influyentes en la investigación sobre la sostenibilidad ambiental universitaria y la relación que existe entre ellos. Para ello, se realizó un análisis de coocurrencias de palabras clave en artículos científicos publicados entre 1989 y 2019, identificándose 23 palabras clave centrales. Luego se diseñó un mapa de asociaciones que muestra las relaciones entre los términos en conglomerados (clusters) temáticos. Se determinó que existen por lo menos tres áreas principales que soportan la investigación sobre la sostenibilidad ambiental en las universidades: educación ambiental, integración de la sostenibilidad ambiental y protección ambiental. Se analiza y se comenta cada una de estas áreas de investigación. 


\section{Introduction}

Environmental problems seem to increase daily (Calixto, 2018). Globally, the most complex issues include climate change, armed conflicts over the exploitation of natural resources, and pollution of air, water, and soil (Osbaldiston \& Schott, 2012). However, the most critical problem may be climate change, which refers to "a change in the state of the climate that can be identified (e.g., by using statistical tests) by changes in the mean and/or the variability of its properties and that persists for an extended period, typically decades or longer" (Intergovernmental Panel on Climate Change [IPCC], 2018, p. 544). But climate change is far from being exclusively an environmental problem (Silvestre \& Tî̀rcă, 2019), considering that it exacerbates issues such as poverty, hunger, and economic recessions, making them more difficult to address (Gasper et al., 2011). Thus, natural resource conservation requires people to recognize that natural resources are finite and that the planet has limited capacities to sustain life (Moldan et al., 2012; Muñoz-Cadena \& Estrada-Izquierdo, 2016).

The concept of environmental sustainability is based on the principles of sustainable development, which was defined by the Brundtland Commission as "development that meets the needs of the present without compromising the ability of future generations to meet their own needs" (World Commission on Environment and Development, 1987, p. 37). Later, when the triple bottom line (TBL) concept was introduced, the environmental sphere began to arouse greater interest in the scientific and academic communities, which started to distinguish this concept from the social and economic spheres while recognizing the relationship of interdependence between them. Originally, the environmental pillar of sustainable development was called "environmentally responsible development", but was later known as "environmentally sustainable development" before finally being renamed "environmental sustainability" (Moldan et al., 2012).

The most widely accepted definition of environmental sustainability was introduced by Goodland (1995), who defined it from the framework of "growth limits" as a development perspective that seeks to improve human well-being by protecting natural resources. While the issue of environmental sustainability has been addressed primarily by private corporations, more recently other types of organizations have also stepped up to the plate, environmental issues being a global concern.

For that reason, a number of initiatives have emerged from higher education (Torres-Cabrera et al., 2015) to address the main environmental challenges facing the planet. Perhaps the most ambitious initiative so far is the Higher Education Sustainability Initiative (HESI), a global network established in 2012 in the runup to the United Nations Conference on Sustainable Development (Rio+20). This network is led by the United Nations Department of Economic and Social Affairs and aims to bring together universities that are willing to commit to teaching sustainable development, fostering research and knowledge dissemination, supporting the development of green campuses and local sustainability initiatives, and engaging in international networks.

In practice, universities are implementing strategies to improve their environmental sustainability performance. The Times Higher Education University Impact Rankings (Table 1), which explores the top 100 universities for climate action, shows how top universities have started implementing actions to reduce greenhouse gas emissions (e.g. University of British Columbia), reducing the environmental footprint on campus (e.g. University of North Carolina at Chapel Hill), incorporating sustainability across the curriculum (e.g. University at Buffalo), increasing energy efficiency (e.g. Laval University), and involving students in climate change conversation (e.g. University of Waterloo) . 
Table 1. Top ten universities leading climate action

\begin{tabular}{cll}
$\begin{array}{c}\text { Climate Action } \\
\text { Rank 2019 }\end{array}$ & \multicolumn{1}{c}{ University } & \multicolumn{1}{c}{ Country } \\
\hline 1 & University of British Columbia & Canada \\
2 & University of North Carolina at Chapel Hill & United States \\
3 & University at Buffalo & United States \\
4 & Laval University & Canada \\
5 & University of Waterloo & Canada \\
6 & Kyoto University & Japan \\
7 & Newcastle University & United Kingdom \\
8 & University of Southampton & United Kingdom \\
9 & KTH Royal Institute of Technology & Sweden \\
10 & Trinity College Dublin & Republic of Ireland \\
\hline
\end{tabular}

Source: Own work based on Times Higher Education University Impact Rankings, 2019.

Although a considerable amount of literature has been published on environmental sustainability in the context of higher education, no previous studies have investigated how this concept has evolved, and little is known about the specific research trends in this field. This indicates a need to identify the most influential topics in environmental sustainability research and the relationship between them.

In order to gain a comprehensive overview of the topic, we employed bibliometric network techniques, aiming to analyze the dynamic nature and patterns of relationships in bibliographic data. Networks are determined based on relationships identified using techniques such as keyword co-occurrence relations or co-authorship relations (Yoo et al., 2019). This study, in particular, employs a keyword co-occurrence analysis.

The importance of identifying the most influential topics in university environmental sustainability studies lies in the possibility of contributing to strengthening lines of research in higher education institutions, associating them with key elements of approaches that regard universities as complex social organizations (Sánchez et al., 2018).

\section{Methods}

\subsection{Data Collection}

We conducted a search in the Scopus electronic database. We chose the Scopus database because it is considered the largest citation database of peer-reviewed literature (Aldieri et al., 2019; 2018; Randhawa et al., 2016). The following combination of keywords was used: "environmental sustainability" AND ("universit*" OR "higher education" OR "tertiary education" OR "post-secondary"). The environmental sustainability search was conducted in the titles, abstracts and keywords of articles while the terms related to higher education were searched only in titles, in order to avoid bias caused by authors' institutional affiliation. As supported by Raban and Gordon (2020), we believe that searching in titles can provide a reasonable and representative sample of the field of study.

Initially, we retrieved 191 publications, from which we selected only those documents published between 1989 and 2019. Then we further restricted the sample to include only scientific articles - on the basis that they have clearer peer-reviewed procedures - that were published in English. The final sample comprised 105 articles (Table 12). The reference information of the publications was imported to Mendeley and downloaded in CVS format, as required by VOSviewer, the tool used to analyze and visualize bibliometric networks. 
Table 2. Study identification

\begin{tabular}{lc}
\hline Stage & $\begin{array}{c}\text { Number of } \\
\text { publications retrieved }\end{array}$ \\
\hline Initial search in Scopus & 191 \\
Year of publication: $<=2019$ & 184 \\
Type of publication: Article & 111 \\
Language: English & 105 \\
\hline Source: Own work based on search conducted in Scopus.
\end{tabular}

\subsection{Data Analysis}

To analyze the publications retrieved, we followed the same procedure performed by Dias et al. (2019) and Terán-Yépez et al. (2020) to analyze scientific publications. Firstly, we present a descriptive analysis of the results, analyzing the number of articles by year of publication and determining the leading journals and most productive countries.

Secondly, we performed a keyword co-occurrence analysis in order to identify the key research themes from 1989 to 2019. This type of analysis is also known as keyword network analysis or co-word network analysis. To analyze keyword network structures, items and ties (links) must be identified. Items are the individual components - in our case, the keywords provided by authors - while ties are the interrelationships among the components (keyword co-occurrences) (Yoo et al., 2019). Items and ties together constitute a network.

Furthermore, between items there can be no more than one link. Each link has a positive numerical value called strength. The higher this value, the stronger the link (Van Eck \& Waltman, 2017). The strength indicates, for instance, the number of publications in which two terms or keywords occur together. In short, a network is a set of items together with the links between the items. A set of items can form clusters. In VOSviewer an item may belong to only one cluster, with clusters labeled using cluster numbers.

To visualize a cluster in a map, we have to consider the weight, which indicates the importance of the item. Items with a higher weight are considered more important than an item with a lower weight. In a keyword co-occurrence map, items with a higher weight are shown more prominently and the color of an item is determined by the cluster to which it belongs. The weight of the item also determines the size of the label and the circle of an item (Van Eck \& Waltman, 2017).

Additionally, we performed a bibliometric analysis called bibliographic coupling to select the articles that were content-analyzed. This method is an effective way to group literature trends graphically based on the co-occurrence of references between two documents. A bibliographic coupling analysis is a citation method that allows researchers to evaluate the degree of similarity between two documents, based on the co-occurrence of their references. The main advantage of this technique, when compared with cocitation or direct citation methods, is that it allows recently published articles to be included (Lerena et al., 2019).

Each article was then read in full and categorized into a cluster according to the topic addressed and the subject of discussion. Thus, cluster 1 includes 12 documents, cluster 2 includes 11 articles, and cluster 3 includes 9 studies. The full-text analysis of the articles in Atlas.ti enabled a broader discussion of the contributions of each study and the similarity between studies. 


\section{Results}

\subsection{Evolution of Scientific Production}

A review of scientific production provides insight into the evolution of the literature of any field of research (Iturralde et al., 2017; Navarro et al., 2017; Terán-Yépez et al., 2020). In that sense, in this first subsection we present descriptive results on the number of articles published by year and determine the leading journals and most productive countries.

Figure 1 shows the number of articles on university environmental sustainability published between 1989 and 2019. Two main periods can be identified: the first from 1994 to 2011, when on average 1.3 articles were published per year, and a second period, between 2012 and 2019, when this figure jumps to an average of 10 articles. We note that the number of articles about environmental sustainability in the context of higher education has increased sharply in the last five years (Figure 1). This is due to increased attention given to serious environmental concerns and the pressure that universities face to implement institutional policies to meet these challenges.

Figure 1. Number of articles published by year

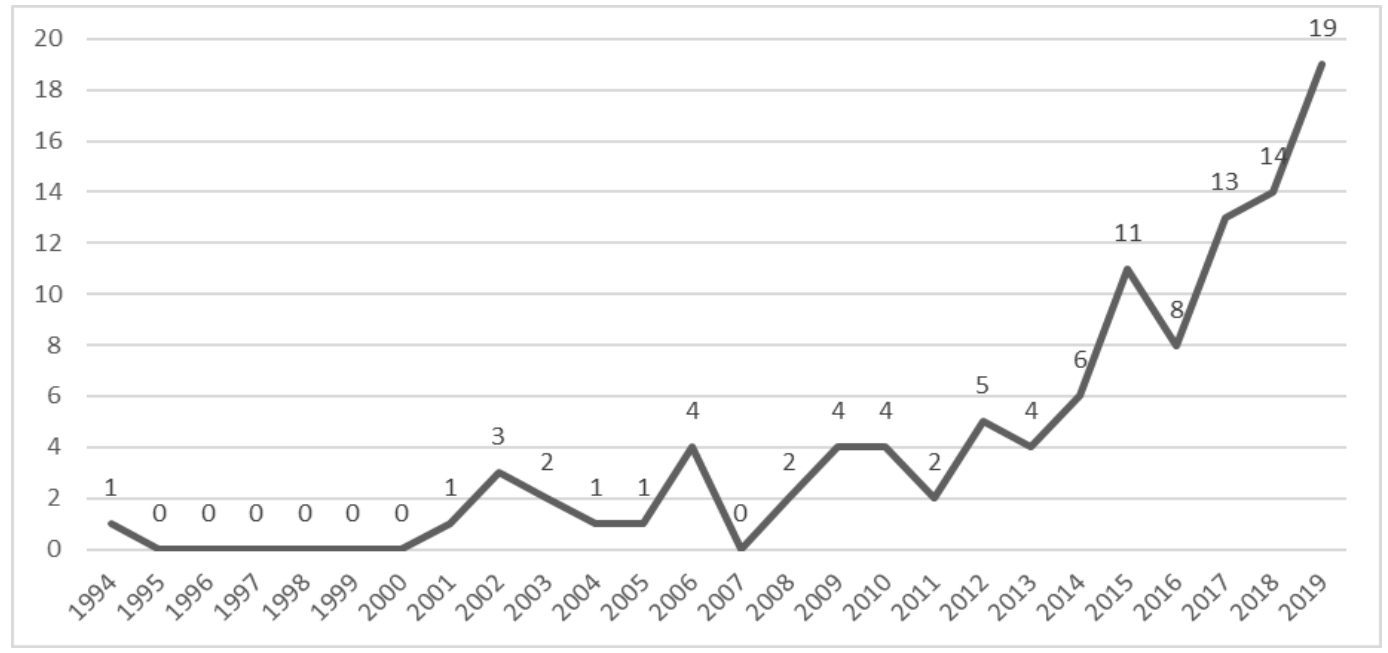

On the other hand, results show that most articles concern the areas of social sciences; environmental science; energy; and business, management and accounting. These four areas make up $79 \%$ of publications. Moreover, the leading journals in university environmental sustainability research are the Journal of Cleaner Production, the International Journal of Sustainability in Higher Education, and Sustainability (Table 3).

The first of these journals covers topics such as sustainable consumption, environmental and sustainability assessment, and education for sustainable development. The second has a clear focus on new advances in sustainability in a higher education context, including topics such as curricular innovation, energy, water, recycling, and waste management. The journal Sustainability, meanwhile, focuses specifically on research on challenges relating to sustainability and socioeconomic, scientific and integrated approaches to sustainable development. 
Table 3. The top 10 most productive journals

\begin{tabular}{lc}
\hline Journal name & $\begin{array}{c}\text { Number } \\
\text { of articles }\end{array}$ \\
\hline Journal of Cleaner Production & 15 \\
International Journal of Sustainability in Higher Education & 13 \\
Sustainability & 6 \\
Environmental Education Research & 4 \\
Higher Education Policy & 3 \\
Resources, Conservation and Recycling & 3 \\
Environmental Engineering and Management Journal & 2 \\
Local Environment & 2 \\
Waste Management & 2 \\
American Journal of Economics and Sociology & 1 \\
\hline
\end{tabular}

The United States accounts for the highest share of publications on environmental sustainability in higher education (30.1\%), followed by the United Kingdom and Australia. Only one Latin American country, Brazil, appears in the list of leading countries (Table 4).

Table 4. Scientific publications by country

\begin{tabular}{lcc}
\hline Country/Territory & Documents & $\%$ \\
\hline United States & 23 & 21.9 \\
United Kingdom & 16 & 15.2 \\
Australia & 14 & 13.3 \\
Canada & 8 & 7.6 \\
Spain & 8 & 7.6 \\
Brazil & 5 & 4.8 \\
\hline
\end{tabular}

Source: Own work based on Scopus search.

\subsection{Influential Keywords in University Environmental Sustainability Research}

A keyword co-occurrence analysis was performed in order to identify the main topics in environmental sustainability research in a higher education context. We selected a threshold of 6 occurrences, which left 24 keywords. They keyword "article", which has no clear meaning, was then excluded from the network, and thus ultimately the 23 most relevant terms were extracted (Table 5). This resulted in a map of associations between terms and their relationships in thematic clusters (Dias et al., 2019). Three thematic areas were identified: environmental education, environmental sustainability integration, and environmental protection. 
Table 5. Cluster analysis

\begin{tabular}{llccc}
\hline Cluster & \multicolumn{1}{c}{ Item } & Links & Strength & Occurrences \\
\hline 1 & Higher education & 22 & 22.00 & 23 \\
& Sustainability & 22 & 36.00 & 43 \\
& University sector & 22 & 18.00 & 18 \\
& Student & 20 & 8.00 & 8 \\
& United States & 20 & 6.00 & 7 \\
& Environmental education & 18 & 9.00 & 9 \\
& Canada & 14 & 6.00 & 6 \\
& Climate change & 11 & 7.00 & 7 \\
& Curriculum & 9 & 6.00 & 7 \\
\hline 2 & Environmental sustainability & 21 & 28.00 & 36 \\
& University & 20 & 15.00 & 18 \\
& Environmental management & 19 & 8.00 & 8 \\
& Universities & 19 & 13.00 & 13 \\
& Education & 18 & 12.00 & 12 \\
& Recycling & 18 & 9.00 & 9 \\
& Waste management & 18 & 8.00 & 8 \\
& Human & 17 & 6.00 & 6 \\
& Sustainable development & 22 & 29.00 & 32 \\
& Environmental protection & 20 & 8.00 & 8 \\
& Environment & 19 & 7.00 & 7 \\
& Environmental impact & 19 & 9.00 & 9 \\
& Students & 19 & 8.00 & 9 \\
& Surveys & 15 & 6.00 & 6 \\
\hline
\end{tabular}

Source: Own work based on keyword clustering.

The whole keyword co-occurrence network is represented in the following map (Figure 2):

Figure 2. Keyword co-occurrence map

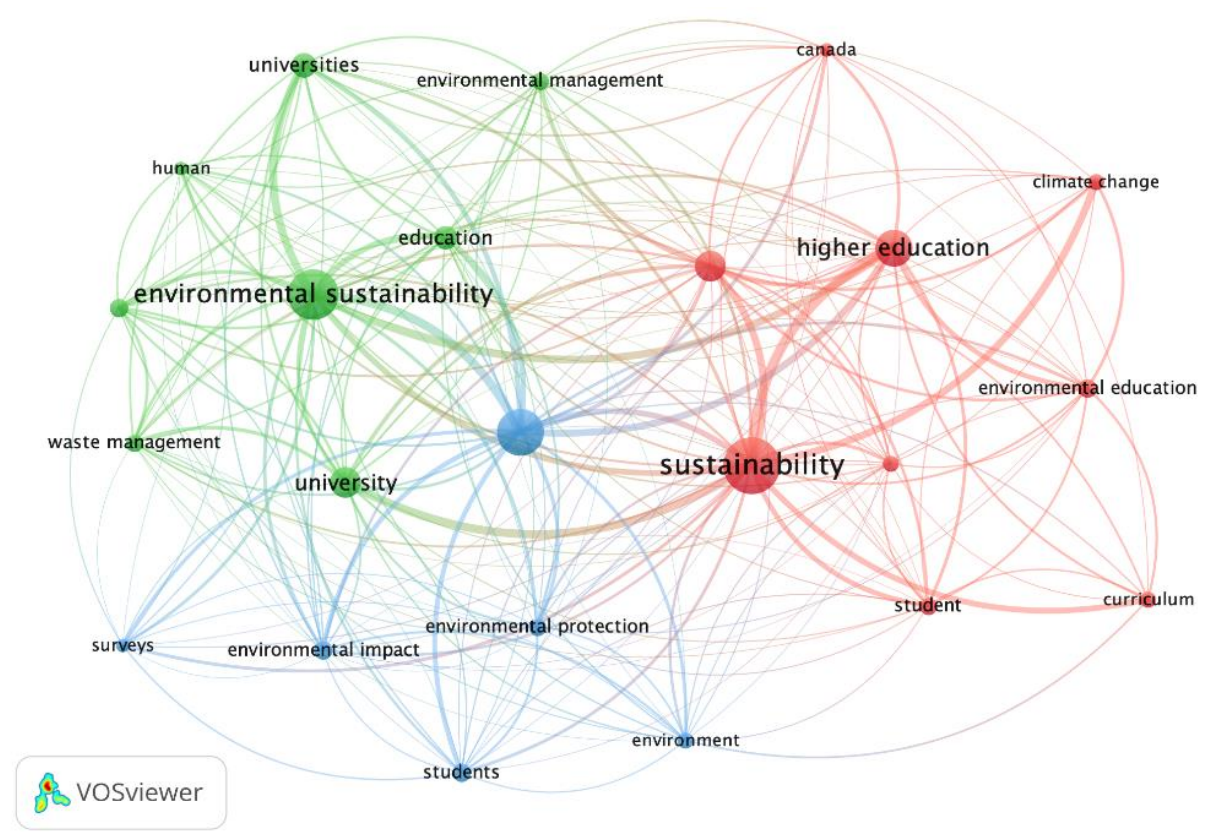




\section{Discussion}

This study aimed to identify the most influential topics in university environmental sustainability research and the relationship between them. We were able to identify 23 core keywords, which resulted in a map of associations between the terms in thematic clusters. We found at least three major areas supporting environmental sustainability research in universities.

\subsection{Environmental Education}

Sustainability education is becoming one of the main missions of universities. Higher education institutions are making increasing efforts in terms of learning, research and operations with the aim of educating for sustainability (Cortese \& Hattan, 2010). However, in practice, these efforts do not always produce the expected results because students and graduates know little about how to align their personal and professional goals with environmental sustainability (Cortese \& Hattan, 2010).

The first cluster of this study focuses on curriculum, environmental education, and education for sustainable development. In a study that set out to determine how to promote environmental education for sustainable development by linking higher education and non-governmental organizations (NGOs), Haigh (2006) draws our attention to the fact that environmental sustainability education is not only a curricular issue. According to Christie et al. (2015), most efforts by universities in environmental sustainability education have focused on management and operations rather than teaching and learning. This may be due to the fact that in many cases, environmental sustainability on campus has been motivated by financial incentives or regulatory pressure (Christie et al., 2015).

Environmental education can be beneficial to sustainable development when it is addressed as a process that goes beyond classrooms and is not restricted to formal education, and when it becomes a lifelong process that is not simply limited to the understanding of environmental sustainability issues. Therefore, the main challenge for environmental sustainability education is pushing the boundaries of formal academic education and achieving an impact on the environmental awareness of not just all students, but all people (Haigh, 2006). Effective practices, for example, include enabling students to conduct research on global problems, case studies, and current sustainability decisions, so that they stay up-to-date in the face of an ever-changing world (Dmochowski et al., 2016). However, when designing strategies, it is important to consider that students may have different socioeconomic, cultural and ethical backgrounds and different academic performance, which may condition their expectations in terms of learning environmental sustainability (Foster, 2010). In the case of teachers, it is important to constantly motivate them to think about their courses and their relationship with sustainability. It is also important to promote collaboration with other teachers and the exchange of academic texts to improve teaching practice (Dmochowski et al., 2016).

Other authors like Clark et al. (2011) analyze the purpose and design of environmental programs. They point out that often these programs fail in their aim to develop training activities with students to enhance their abilities as problem solvers due to three weaknesses: 1) a lack of clarity about the core goals of environmental programs, leading the participants to replace them with goals that may not be relevant; 2 ) the poor alignment of multiple academic disciplines into environmental programs, due to ineffective frameworks and communication; 3) a diverse array of perspectives, pedagogies, methodologies, and courses, which makes it even more difficult for students to acquire, integrate and apply knowledge about environmental issues.

Pesonen (2003) emphasizes the importance of including environmental aspects not only at the undergraduate level but also higher levels of training like master's degrees. For example, for a corporate environmental management course, Pesonen (2003) argues that it is important to consider at least three components: 1) identifying the environmental impacts of organizations and products; 2) environmental impact management; and 3) creation of eco-competitiveness. Thus, as can be seen, in this cluster, curricular issues are one of the main topics addressed. In the same vein, Hurlimann (2009), referring 
specifically to disciplines such as urban planning, maintains that students wish to be trained in at least the following aspects: open space planning, sustainable transportation planning, energy efficiency, and environmental systems. Paradoxically, students consider that the climate change adaptation and mitigation teaching they receive is inadequate, which points to a need for increased awareness-raising given that mitigation and adaptation are two fundamental pillars for tackling climate change.

Finally, other articles selected for analysis in this cluster focus on the conceptualization or operationalization of sustainability in the context of higher education. Aleixo et al. (2018) stress that sustainability in universities can be developed from different areas: campus operations, community engagement, institutional frameworks, on-campus experiences, research, education, and assessment and reporting. For Marta et al. (2018), the integration of leaders, faculty, administrative staff, students and external stakeholders should be a fundamental part of any university environmental sustainability strategy. On the other hand, Wright and Wilton (2012) found, in a sample of facilities management directors, that the term environmental sustainability is generally associated with minimal impact generation on the environment and reduced use of natural resources. Understanding how sustainability is conceptualized by members of the university community is an early stage in all institutional policymaking processes, because this term can take on different meanings depending on the context and the person (Wright \& Wilton, 2012).

\subsection{Environmental Sustainability Integration}

Cluster 2 involves the main concept of this study (environmental sustainability) as well as terms related to recycling and waste management in the higher education context. The articles in this cluster have been critically analyzed in order to identify the most discussed aspects surrounding the integration of environmental sustainability into higher education institutions. We wish to start by noting that the integration of environmental sustainability into higher education responds to institutional pressures (Wright, 2002).

It could be said that the interest in integrating environmental concerns into universities stems from principles, initiatives and statements such as the Stockholm Declaration on the Human Environment (1977), the Ninth International Association of Universities Round Table: The Kyoto Declaration (1993) or the International Conference on Environment and Society-Education and Public Awareness for Sustainability: Declaration of Thessaloniki (1997) (Wright, 2002), which have led universities to adopt strategies to contribute to major global issues. However, universities sometimes adhere to these initiatives only for public relations purposes and not out of a genuine interest in environmental sustainability (Wright, 2002).

Supporting the arguments of Wright (2002), Ralph and Stubbs (2014) maintain that while it is important that universities adhere to international initiatives, in most cases these initiatives fail to become effective actions, resulting in few systemic transformations. For instance, according to Ralph and Stubbs (2014), universities have so far focused on recognizing the impact of energy use or waste generated, thus increasing the number of universities concerned with reducing the ecological footprint of their campuses, but which experience serious difficulties in the development of "green" curricula. This has some impact on campus operations but achieves little progress in environmental sustainability in intellectual and conceptual terms (Zen et al., 2016). At the same time, the number of universities reporting their actions on initiatives like Global Compact grows at a slower pace than the number of commercial businesses does.

By this we do not mean that sustainable campus strategies are inadequate. On the contrary, sustainable campuses are a policy widely adopted by universities, but they are not, per se, a guarantee of environmental sustainability. Environmental sustainability is about much more: students, teachers and administrative staff are required to engage in real problems and actively engage in generating solutions (Filho et al., 2017). As Filho et al. (2017) suggest, there is a need to go beyond the mere dissemination of information; if you really hope to change attitudes and behaviors, it is important to engage the 
community, reform curricula, and determine governance mechanisms.

Also in reference to barriers to the integration of environmental sustainability, but adopting a microperspective, Lozano (2006) analyzes the reasons why sustainability has not really been incorporated and implemented throughout most universities across the world. Lozano (2006) argues that the poor adoption of environmental sustainability initiatives by university institutions is largely due to individual barriers associated with resistance to change, and posits at least three barriers that make it difficult to integrate environmental sustainability into universities. The first relates to resistance to the idea itself, that is, resistance generated by the lack of information or the lack of a clear statement on the subject or because we disagree with the idea. The second barrier relates to a sense of loss of control, power, or status, which can lead to feelings of incapacity. The third type of barrier is associated with values: for example, the person may be aware that change is necessary, but disagrees as a result of cultural differences or religious, sexual or other beliefs.

Faced with the problem of a lack of real commitment from universities in adopting environmental sustainability strategies, Filho et al. (2015) suggest that the main concern for universities discussing environmental sustainability should be how to translate sustainability into real practices that transform society. According to Filho et al. (2015), universities could make a real impact if they are able to develop holistic approaches that include strategies related to curriculum, the campus, the community, and research. However, although this is an internal issue for universities, it should be well understood that environmental sustainability issues require interdisciplinary solutions developed with multiple external stakeholders.

Finally, this cluster includes five case studies that describe the experiences of university institutions in environmental sustainability. Case studies are a research design that offers a deeper insight into the research phenomenon. One of the case studies (Zhang et al., 2011) highlights how sustainable waste management has positioned the University of Southampton as one of the leading universities in environmental sustainability. In a similar way to Lozano (2006), Zhang et al. (2011) found that resistance to change is one of the most recurrent barriers and has been the biggest obstacle to developing sustainability projects. Despite this, the university's success in implementing its sustainability strategy was largely due to the integration of students through both traditional and creative methods, thereby making them think for themselves about how and why they should care about recycling.

Another case study focuses on Michigan State University students and shows that the student community is aware of the benefits of recycling, but lacks sufficient knowledge about which materials can be recycled and where (Kaplowitz et al., 2009). However, overall the results of the study are not negative; on the contrary, they suggest that students may be very interested in learning about the recycling process and that sustainability policymakers should conduct communication campaigns that do much more than just explain the reasons for recycling.

The third case study describes a project to examine the environmental and economic impacts of composters at Kean University (Mu et al., 2016). This space has helped students to gain familiarity with and relate to sustainable technologies and real environmental problems. The fourth case study focuses on building a culture of environmental sustainability at the University of Michigan (UM) (Levy \& Marans, 2012). The practical recommendations put forward by the authors to promote the development of proenvironmental behaviors revolve around three main dimensions: education (through online tutorials, certified courses for managers and staff, training courses for teachers on how to integrate sustainability into curricula); engagement (open calls for ideas, competitions on recycling or energy use, provision of funds); and evaluation and monitoring (development of indicators, promotion of a culture of measurement and reporting of environmental performance).

The fifth and final case study focuses on Vytautas Magnus University (VMU), Lithuania, and highlights the role of this institution in the development of environmental sustainability policies, internally (as an organization) and externally (as an agent of the region) (Dagiliūtè \& Liobikienè, 2015). The authors 
conclude that universities, through sustainable policy, research, curriculum, and their role in the region, can have a significant impact on society, stressing, as we mentioned at the beginning of this discussion, that each university is under ever greater national and international pressure to engage in more profound environmental sustainability actions.

\subsection{Environmental Protection}

How to lead people to adopt pro-environmental behaviors? This question serves as a basis for several articles in this cluster. Environmental awareness, in the words of Talay et al. (2004), is defined as care, concern, and sensitivity to environmental problems. However, just being conscious is not enough; saving the planet requires that people adopt more rational consumption habits and a lifestyle based on environmental protection. The problem in the case of developing countries, as explained by Talay et al. (2004), is that it becomes difficult to change behaviors and attitudes towards the environment in contexts where people are struggling just to survive and therefore find it harder to give any thought to environmentally sustainable habits.

Yuan et al. (2013) report that students are more aware of sustainability issues than their parents and faculty members. However, all three groups seem to be more aware of global or local environmental issues than university environmental concerns. Yuan et al. (2013) analyzed environmental sustainability, sustainable curricula, staff development and rewards, research and development, student opportunities, awareness of management systems, and social responsibility.

While promoting environmental behaviors is an arduous task due to an often muddled understanding of the concept of "sustainability" in the curriculum, research and campus operations context (Mader, 2013), the difficulty of addressing the problem of environmental protection should not deter us from seeking to do so. For this reason, universities, as educational and life-training centers, play a fundamental role in safeguarding the planet. In that sense, Grady-Benson and Sarathy (2016) point to a shift from individual environmental responsibility to collective mobilization, whereas in the second cluster of this study, most authors described the development of individual actions, from a university as an organization or institution, to reduce the carbon footprint. What Grady-Benson and Sarathy (2016) suggest is for students to act collectively on campus and join national movements to tackle climate policies that compromise the well-being of the planet.

To achieve collective mobilization, for Grady-Benson and Sarathy (2016), first it is necessary to understand how students perceive environmental problems. For this reason, one of the main contributions by Campbell-Arvai (2015) in relation to the promotion of environmentally responsible habits to prevent food waste in universities is a three-strategy approach: 1) conducting campus-wide campaigns that call on students to assess their food choices and environmental impacts; 2) university executives should make efforts to purchase food with little environmental impact in terms of plastic or non-organic waste, for example; and 3) developing environmentally friendly interventions to promote healthy habits and pro-environmental and pro-social behaviors. Also, in reference to interventions to improve students' awareness in terms of meal choices, Whitehair and Shanklin (2012) suggest using simple messages with students to introduce behavioral changes to address food waste.

In addition, there are two studies in this cluster that are closely related because they mainly address reducing the environmental impact within universities. Iriarte et al. (2015), for example, analyze greenhouse gas emissions at the University of Talca (Chile) using the Greenhouse Gas Protocol Corporate Standard (the GHG Protocol) by the World Resources Institute (WRI). In particular, we consider this to be a robust methodology that could be replicated by Latin American universities, because it measures direct emissions from fuel consumption and student commuting by an institutional bus and fugitive and indirect emissions from the organization's electricity consumption. Lukman et al. (2018) also set out the case of a university's environmental impact assessment in Slovenia, but unlike Iriarte et al. (2015), they report the use of a life cycle assessment (LCA) methodology. The main dimensions proposed by this methodology are the construction and demolition of buildings, cleaning, heating, lighting, painting, materials, 
and waste management.

Finally, Sáez-Martínez et al. (2014) set out the fundamental role of universities in achieving sustainable innovations in partnership with companies, researchers and citizens, among other agents, as part of innovation ecosystems. This is another route that universities have taken in recent years in order to contribute to sustainable development while strengthening their social and relational capital. Collaboration between universities and other agents to achieve sustainable innovations (i.e. circular economy, waste management, sustainable packaging) is much more complex than collaboration for traditional innovations, because environmental issues demand the involvement of a much larger number of agents, who may have different interests.

\section{Conclusions}

We believe this research provides some important insights to education policymakers, teachers, and students, as well as university managers interested in improving knowledge of environmental issues in the context of higher education. First, we identify three major themes that can guide future research. We also believe this study may be of great interest to both academics and decision-makers, as it can serve as an input to establish thematic lines of research.

Based on the results, we believe that more studies on environmental sustainability are required in the Latin American context, because the region is as yet underrepresented. We also suggest that future studies compare the environmental performance of universities (integration in the curriculum, carbon footprint, environmental impact) at the regional and country level, and that they employ large samples of students, teachers, administrative staff, community members and other stakeholders to analyze the phenomenon of environmental sustainability in the university context, because until now results have been chiefly based on case studies.

We close by outlining the main limitations of our study. The first limitation relates to the choice of database; future studies could integrate more databases in order to include a larger body of literature. Secondly, this study does not engage with other spheres of sustainability; future research could identify how universities address social and economic issues, or the interaction between all these spheres, from a triple bottom line (TBL) perspective. The reader should also consider that the possible association established between the main concepts is based on a network analysis; future literature reviews could include an in-depth analysis of the literature to complement this keyword network analysis.

\section{References}

Aldieri, L., Carlucci, F., Vinci, C. P., \& Yigitcanlar, T. (2019). Environmental innovation, knowledge spillovers and policy implications: A systematic review of the economic effects literature. Journal of Cleaner Production, 239, 118051. https://doi.org/10.1016/i.jclepro.2019.118051

Aleixo, M. A., Leal, S., \& Miranda, U. (2018). Conceptualization of sustainable higher education institutions, roles, barriers, and challenges for sustainability: An exploratory study in Portugal. Journal of Cleaner Production, 172, 1664-1673. https://doi.org/10.1016/j.jclepro.2016.11.010

Calixto, R. (2018). El cambio climático en las representaciones sociales de los estudiantes universitarios [Climate change in university students' social representations]. Revista Electrónica de Investigación Educativa, 20(1), 122-132. https://doi.org/10.24320/redie.2018.20.1.1443

Campbell-Arvai, V. (2015). Food-related environmental beliefs and behaviours among university undergraduates: A mixed-methods study. International Journal of Sustainability in Higher Education, 16(3), 279-295. https://doi.org/10.1108/IJSHE-06-2013-0071 
Christie, B. A., Miller, K. K., Cooke, R., \& White, J. G. (2015). Environmental sustainability in higher education: What do academics think? Environmental Education Research, 21(5), 655-686.

https://doi.org/10.1080/13504622.2013.879697

Clark, S. G., Rutherford, M. B., Auer, M. R., Cherney, D. N., Wallace, R. L., Mattson, D. J., Clark, D. A., Foote, L., Krogman, N., Wilshusen, P., \& Steelman, T. (2011). College and university environmental programs as a policy problem (Part 2): Strategies for improvement. Environmental Management, 47(5), 716-726.

https://doi.org/10.1007/s00267-011-9635-2

Cortese, A. D., \& Hattan, A. S. (2010). Research and solutions: Education for sustainability as the mission of higher education. Sustainability, 3(1), 48-52. https://doi.org/10.1089/SUS.2009.9802

Dagiliūtè, R., \& Liobikienè, G. (2015). University contributions to environmental sustainability : challenges and opportunities from the Lithuanian case. Journal of Cleaner Production, 1-9.

https://doi.org/10.1016/j.jclepro.2015.07.015

Dias, C. S. L., Rodrigues, R. G., \& Ferreira, J. J. (2019). Agricultural entrepreneurship: Going back to the basics. Journal of Rural Studies, 70, 125-138. https://doi.org/10.1016/i.jrurstud.2019.06.001

Dmochowski, J. E., Garofalo, D., Fisher, S., Greene, A., \& Gambogi, D. (2016). Integrating sustainability across the university curriculum. International Journal of Sustainability in Higher Education, 17(5), 1-27.

https://doi.org/10.1108/IJSHE-10-2014-0154

Filho, W. L., Brandli, L. L., Becker, D., Skanavis, C., Kounani, A., Sardi, C., Paço, A., Azeiteiro, U., Sousa, L., Raath, S., Pretorius, R. W., Vargas, V., Trencher, G., Marans, R. W., Papaioannidou, D., Paço, A., Azeiteiro, U., Sousa, L., Raath, S., \& Pretorius, R. W. (2017). Sustainable development policies as indicators and preconditions for sustainability efforts at universities: Fact or fiction? International Journal of Sustainability in Higher Education, 1-34. https://doi.org/10.1108/IJSHE-01-2017-0002

Filho, W. L., Shiel, C., \& do Paço, A. (2015). Integrative approaches to environmental sustainability at universities: An overview of challenges and priorities. Journal of Integrative Environmental Sciences, 12(1), 1-14. https://doi.org/10.1080/1943815X.2014.988273

Foster, J. (2010). Sustainability, higher education and the learning society. Environmental Education Research, 8(1), 37-41. https://doi.org/10.1080/13504620120109637

Gasper, R., Blohm, A., \& Ruth, M. (2011). Social and economic impacts of climate change on the urban environment. Current Opinion in Environmental Sustainability, 3(3), 150-157.

https://doi.org/10.1016/i.cosust.2010.12.009

Goodland, R. (1995). The concept of environmental sustainability. Annual Review of Ecology and Systematics, 26, 1-24. https://doi.org/10.1146/annurev.es.26.110195.000245

Grady-Benson, J., \& Sarathy, B. (2016). Fossil fuel divestment in US higher education: Student-led organising for climate justice. Local Environment, 21(6), 661-681.

https://doi.org/10.1080/13549839.2015.1009825

Haigh, M. J. (2006). Promoting environmental education for sustainable development: The value of links between higher education and non-governmental organizations (NGOs). Journal of Geography in Higher Education, 30(2), 327-349. https://doi.org/10.1080/03098260600717422 
Hurlimann, A. C. (2009). Responding to environmental challenges: an initial assessment of higher education curricula needs by Australian planning professionals. Environmental Education Research, 15(6), 643-659. https://doi.org/10.1080/13504620903244159

Intergovernmental Panel on Climate Change. (2018). Global Warming of $1.5^{\circ} \mathrm{C}$. An IPCC Special Report on the impacts of global warming of $1.5^{\circ} \mathrm{C}$ above pre-industrial levels and related global greenhouse gas emission pathways, in the context of strengthening the global response to the threat of climate change, sustainable development, and efforts to eradicate poverty. https://www.ipcc.ch/sr15/chapter/glossary/

Iriarte, A., Almeida, M., Villalobos, P., \& Leonardo, V. (2015). Evaluation of greenhouse gas emissions and proposals for their reduction at a university campus in Chile. Journal of Cleaner Production, 1-7. https://doi.org/10.1016/j.jclepro.2015.06.073

Iturralde, M. C., Bravo, B. M., \& Flores, A. (2017). Agenda actual en investigación en didáctica de las Ciencias Naturales en América Latina y el Caribe [Current agenda in teaching research in the natural sciences in Latin America and the Caribbean]. Revista Electrónica de Investigación Educativa, 19(3), 49-59. https://doi.org/10.24320/redie.2017.19.3.905

Kaplowitz, M. D., Yeboah, F. K., Thorp, L., \& Wilson, A. M. (2009). Garnering input for recycling communication strategies at a Big Ten University. Resources, Conservation and Recycling, 53, 612-623.

https://doi.org/10.1016/i.resconrec.2009.04.018

Lerena, O., Barletta, F., Fiorentin, F., Suárez, D., \& Yoguel, G. (2019). Big data of innovation literature at the firm level: A review based on social network and text mining techniques. Economics of Innovation and New Technology, 1-17. https://doi.org/10.1080/10438599.2019.1684646

Levy, B. L. M., \& Marans, R. W. (2012). Towards a campus culture of environmental sustainability: Recommendations for a large university. International Journal of Sustainability in Higher Education, 13(4), 365-377. https://doi.org/10.1108/14676371211262317

Lozano, R. (2006). Incorporation and institutionalization of SD into universities: Breaking through barriers to change. Journal of Cleaner Production, 14(9-11), 787-796.

https://doi.org/10.1016/j.jclepro.2005.12.010

Lukman, R., Tiwary, A., \& Azapagic, A. (2018). Towards greening a university campus: The case of the University of Maribor, Slovenia. Resources, Conservation \& Recycling, 53(11), 639-644.

https://doi.org/10.1016/j.resconrec.2009.04.014

Mader, C. (2013). Effective change management, governance and policy for sustainability transformation in higher education. Sustainability Accounting, Management and Policy Journal, 4(3), 264-284.

https://doi.org/10.1108/SAMPJ-09-2013-0037

Marta, A., Leal, S., \& Miranda, U. (2018). Conceptualization of sustainable higher education institutions , roles, barriers, and challenges for sustainability: An exploratory study in Portugal. Journal of Cleaner Production, 172, 1664-1673. https://doi.org/10.1016/j.jclepro.2016.11.010

Moldan, B., Janoušková, S., \& Hák, T. (2012). How to understand and measure environmental sustainability: Indicators and targets. Ecological Indicators, 17, 4-13.

https://doi.org/10.1016/i.ecolind.2011.04.033

Mu, D., Horowitz, N., Casey, M., \& Jones, K. (2016). Environmental and economic analysis of an in-vessel food waste composting system at Kean University in the U.S. Waste Management, 59, 476-486.

https://doi.org/10.1016/j.wasman.2016.10.026 
Muñoz-Cadena, C. E., \& Estrada-Izquierdo, I. E. (2016). Logros de la educación ambiental y la sustentabilidad urbana en México [Accomplishments of environmental education and urban sustainability in Mexico]. Revista Electrónica de Investigación Educativa, 18(3), 37-50.

http://redie.uabc.mx/redie/article/view/1192

Navarro, L., Cuevas, O., \& Martínez, J. M. (2017). Meta-análisis sobre educación vía TIC en México y América Latina [A meta-analysis of ICT-based education in Mexico and Latin America]. Revista Electrónica de Investigación Educativa, 19(1), 10-20. https://doi.org/10.24320/redie.2017.19.1.1217

Osbaldiston, R., \& Schott, J. P. (2012). Environmental sustainability and behavioral science: Meta-analysis of proenvironmental behavior experiments. Environment and Behavior, 44(2), 257-299.

https://doi.org/10.1177/0013916511402673

Pesonen, H.-L. (2003). Challenges of integrating environmental sustainability issues into business school curriculum: A case study from the University of Jyväskylä, Finland. Journal of Management Education, 27(2), 158-171. https://doi.org/10.1177/1052562903251412

Raban, D. R., \& Gordon, A. (2020). The evolution of data science and big data research: A bibliometric analysis. Scientometrics, 122(3), 1563-1581. https://doi.org/10.1007/s11192-020-03371-2

Ralph, M., \& Stubbs, W. (2014). Integrating environmental sustainability into universities. Higher Education, 67, 71-90. https://doi.org/10.1007/s10734-013-9641-9

Randhawa, K., Wilden, R., \& Hohberger, J. (2016). A bibliometric review of open innovation: Setting a research agenda. Journal of Product Innovation Management, 33(6), 750-772.

https://doi.org/10.1111/ipim.12312

Sáez-Martínez, F. J., González-Moreno, Á., Hogan, T., Jose Saez-Martinez, F., Gonzalez-Moreno, A., \& Hogan, T. (2014). The role of the University in eco-entrepreneurship: Evidence from the Eurobarometer Survey on Attitudes of European Entrepreneurs towards Eco-innovation. Environmental Engineering and Management Journal, 13(10), 2541-2549. https://doi.org/10.30638/eemj.2014.284

Sánchez, J., Miranda, L., \& Viloria, J. (2018). Implicaciones de los estudios organizacionales para la resignificación de la gestión de las organizaciones educativas [Implications of organizational studies for the resignification of educational organization management]. In M. Gregorio, P. Mandiola, R. M. Isla, \& N. Ríos (Eds.), Nuevas formas de organización y trabajo: Latinoamérica frente a los actuales desafíos económicos, sociales y medioambientales (pp. 572-580). Red de Posgrados de Investigación Latinos en Administración y Estudios Organizacionales.

Silvestre, B. S., \& Tîrcă, D. M. (2019). Innovations for sustainable development: Moving toward a sustainable future. Journal of Cleaner Production, 208, 325-332.

https://doi.org/10.1016/j.jclepro.2018.09.244

Talay, I., Gündüz, S., \& Akpınar, N. (2004). On the status of environmental education and awareness of undergraduate students at Ankara University, Turkey. International Journal of Environment and Pollution, 21(3), 293-308. https://doi.org/10.1504/IJEP.2004.004196

Terán-Yépez, E., Marín-Carrillo, G. M., Casado-Belmonte, M. del P., \& Capobianco-Uriarte, M. de las M. (2020). Sustainable entrepreneurship: Review of its evolution and new trends. Journal of Cleaner Production, 252, 1-21. https://doi.org/10.1016/j.jclepro.2019.119742

Times Higher Education University Impact Rankings. (2019). Top universities for climate action. https://www.timeshighereducation.com/student/best-universities/top-universities-climate-action 
Torres-Cabrera, M. A., Vélez-Peláez, J. M., \& Altamar-Bula, F. (2015). The quality of higher education in Colombia. An econometric approach (2007-2012). Clío América, 9(18),143-156.

http://revistas.unimagdalena.edu.co/index.php/clioamerica/article/view/1532

Van Eck, N. J., \& Waltman, L. (2017). Manual for VOSviewer versión 1.6.6.

Whitehair, K. J., \& Shanklin, C. W. (2012). Written messages improve beliefs and edible food waste behaviors in a university dining facility. JAND, 112(9), A54. https://doi.org/10.1016/i.jand.2012.06.192

World Commission on Environment and Development. (1987). Report of the World Commission on Environment and Development. In Our Common Future, From One Earth to One World.

https://sustainabledevelopment.un.org/content/documents/5987our-common-future.pdf

Wright, T. S. A. (2002). Definitions and frameworks for environmental sustainability in higher education. Higher Education Policy, 15(2), 105-120. https://doi.org/10.1016/S0952-8733(02)00002-8

Wright, T. S. A., \& Wilton, H. (2012). Facilities management directors' conceptualizations of sustainability in higher education. Journal of Cleaner Production, 31, 118-125.

https://doi.org/10.1016/j.jclepro.2012.02.030

Yoo, S., Jang, S., Byun, S. W., \& Park, S. (2019). Exploring human resource development research themes: A keyword network analysis. Human Resource Development Quarterly, 30(2), 155-174.

https://doi.org/10.1002/hrdq.21336

Yuan, X., Zuo, J., \& Huisingh, D. (2013). Green Universities in China - what matters? Journal of Cleaner Production, 61, 36-45. https://doi.org/10.1016/j.jclepro.2012.12.030

Zen, I. S., Subramaniam, D., Sulaiman, H., Saleh, A. L., Omar, W., \& Salim, M. R. (2016). Institutionalize waste minimization governance towards campus sustainability: A case study of Green Office initiatives in Universiti Teknologi Malaysia. Journal of Cleaner Production, 135, 1407-1422.

https://doi.org/10.1016/i.jclepro.2016.07.053

Zhang, N., Williams, I. D., Kemp, S., \& Smith, N. F. (2011). Greening academia: Developing sustainable waste management at Higher Education Institutions. Waste Management, 31(7), 1606-1616.

https://doi.org/10.1016/i.wasman.2011.03.006 